\title{
First description of adults of the type species of the genus Glossocercus Chandler, 1935 (Cestoda: Gryporhynchidae)
}

\author{
Mirza P. Ortega-Olivares ${ }^{1}$, Rogelio Rosas-Valdez ${ }^{1}$ and Martín García-Varela ${ }^{2}$ \\ ${ }^{1}$ Departamento de Zoología, Instituto de Biología, Universidad Nacional Autónoma de México, Avenida Universidad 3000 , \\ Ciudad Universitaria, C.P. 04510, México, D. F., Mexico; \\ ${ }^{2}$ Unidad Académica de Ciencias Biológicas, Universidad Autónoma de Zacatecas, Calzada de la Revolución Mexicana S/N, \\ Col. Tierra y Libertad, Apdo. Postal 12, 986000, Guadalupe, Zacatecas, México
}

\begin{abstract}
The type species of the genus Glossocercus Chandler, 1935, G. cyprinodontis Chandler, 1935, was described as metacestode (larval stage) from the mesentery of the sheepshead minnow fish (Cyprinodon variegatus Lacépède) from Galveston Bay, Texas. The description was based on the morphology of the rostellar hooks; however, the features of the internal morphology of the proglottides could no be provided. In the present study we describe for the first time the features of the adult G. cyprinodontis from the intestine of Pelecanus occidentalis Linnaeus, Nycticorax nycticorax Linnaeus and Egretta rufescens Gmelin in Mexico. Glossocercus cyprinodontis possesses similar strobilar morphology with the two other congeneric species, both distributed in the Neartic and Neotropical regions, i.e. Glossocercus caribaensis (Rysavy et Macko, 1971) and Glossocercus auritus (Rudolphi, 1819). However, G. cyprinodontis differs mainly in the shape of the rostellar hooks (those of G. cyprinodontis possess the handle and the guard strongly sclerified compared to those of G. auritus and G. caribaensis) and their size (total length of 175-203 $\mu \mathrm{m}$ in G. cyprinodontis compared to 189-211 $\mu \mathrm{m}$ in G. caribaensis and 220-285 $\mu \mathrm{m}$ in G. auritus). Generic diagnosis of Glossocercus is emended: rostellar hooks in two rows with ten hooks of different shape and length in each, scolex large and globular, proglottides craspedote, wider than long, genital pores irregularly alternating, vagina transverse, surrounded by epithelial cells, ventral to cirrus-sac, uterus bar-shaped in mature proglottides, occupies all space between osmoregulatory ducts with eggs in gravid proglottides, ovary lobed in middle of proglottis, cirrus-sac elongate, between osmoregulatory canals, cirrus armed with spinitriches and apical tuft of slender spinitriches.
\end{abstract}

Keywords: morphology, type species, strobilar morphology, Cyclophillidea, Glossocercus cyprinodontis, Pelecanus, Egretta, Nycticorax, Gulf of Mexico, principal component analysis

Glossocercus Chandler, 1935 (Gryporhynchidae) is a genus of cyclophyllidean cestodes that includes intestinal parasites of pelicans, herons and freshwater turtles distributed in America, Africa, Australia and Indonesia (Bona 1994, Pichelin et al. 1998). Currently, the genus contains nine species: Glossocercus cyprinodontis Chandler, 1935 (type species), G. auritus (Rudolphi, 1819), G. glandularis (Fuhrmann, 1905), G. ardeae (Johnston, 1911), G. chelodinae (MacCallum, 1921), G. clavipera (Baer et Bona, 1960), G. paracyclorchida (Baer et Bona, 1960), G. megascolecina (Ukoli, 1967) and G. caribaensis (Rysavy et Macko, 1971) (Bona 1994, Pichelin et al. 1998). Morphologically, these nine species are characterized by the hook pattern 'glossocercoid' defined as hooks with massive sclerification in the handle and guard, long blade and strong to reduced beak; two discontinuous lines in sclerified structure separate the handle and the guard from the hook body and blade (see Pichelin et al. 1998).

The type species Glossocercus cyprinodontis was described from metacestodes found in the mesentery of sheepshead minnow fish (Cyprinodon variegatus Lacépède) from Galveston Bay, Texas, USA and a new genus, Glossocercus, was proposed to accommodate it (Chandler 1935). Metacestodes are a larval stage of cestodes, and consequently the description of this type species of Glossocercus was restricted to morphological features of the scolex, principally to rostellar hooks (see Chandler 1935), and morphological traits of the adult remained unknown. Ortega-Olivares et al. (2008) collected adults of G. cyprinodontis from the intestine of herons in the Yucatán, Mexico, but they did not provide morphological description of these tapeworms.

During a helminthological survey on the helminth parasites of aquatic birds in Mexico, we collected adult tapeworms conspecific with G. cyprinodontis in fisheating birds in lagoons of the Gulf of Mexico. In this paper, the morphological characters of the adult of this tapeworm are described for the first time and the generic diagnosis of Glossocercus is emended. 


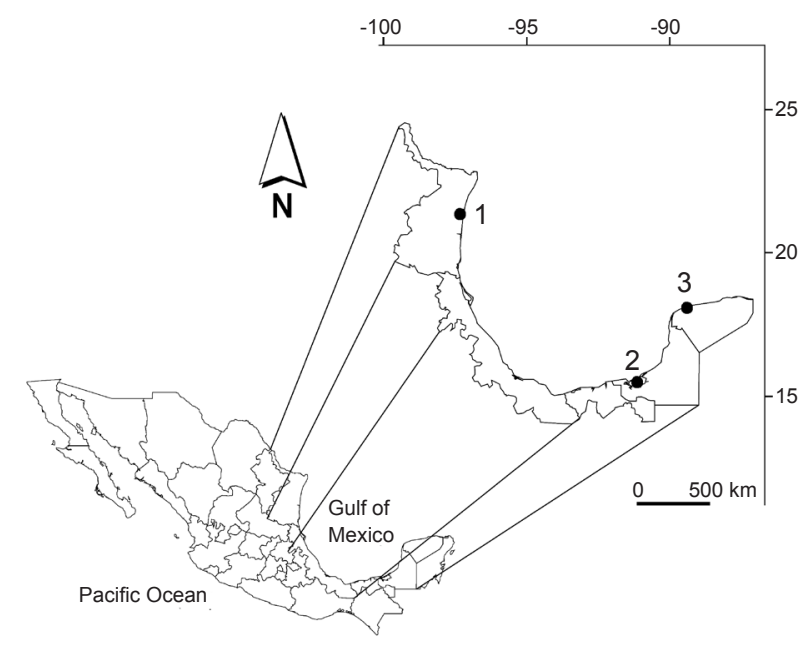

Fig. 1. Bird collection sites in the Gulf of Mexico where the adults of Glossocercus cyprinodontis were found. 1 - Punta Piedra, Tamaulipas; 2 - Laguna de Términos, Campeche; 3 - Chuburná, Yucatán.

\section{MATERIALS AND METHODS}

\section{Specimen collection and preparation}

We collected 180 fish-eating birds between June 2006 and April 2011 in 19 localities in Mexico from coasts of the Pacific Ocean and the Gulf of Mexico. However, tapeworms were recorded only in three localities from the Gulf of Mexico (see Fig. 1; Table 1). Hosts were killed with a shotgun, under collecting permit FAUT No. 0202. After capture, the intestinal tract was removed from the body, placed in Petri dishes with saline $(0.75 \%)$ and examined using a stereoscopic microscope. Tapeworms were removed from the lumen of the intestine, washed in saline, fixed with $4 \%$ hot formalin and stored in ethanol (70\%). In the laboratory, the cestodes were stained with Schuberg's hydrochloric carmine or Mayer's paracarmin, and mounted on permanent slides with Canada balsam. Specimens were deposited in the Colección Nacional de Helmintos (acronym CNHE), at the Instituto de Biología, Universidad Nacional Autónoma de México, Mexico City and U.S. National Parasite Collection (USNPC), Beltsville, Maryland, USA.

\section{Morphological examination}

Identification was based on morphological criteria following the original description (Chandler 1935) and features reported by Scholz et al. (2004) and Ortega-Olivares et al. (2008). A paratype of G. cyprinodontis deposited in the U.S. National Parasite Collection (No. 39528) was also examined. The present description of the adult is based on 18 stained specimens obtained from different hosts. Drawings were made with the aid of a drawing tube. Measurements of morphological characters are given as minimum and maximum in $\mu \mathrm{m}$ (unless otherwise stated), followed by mean and number of specimens measured (n) in parentheses. Measurements of the testes, cirrus-sac, vagina and seminal receptacle were obtained from fully mature proglottides.

\section{Principal component analysis}

Morphometric comparisons using the principal component analysis (PCA) were carried out to evaluate morphometric differences between tapeworms from different hosts. We used PCA as a purely descriptive tool, with the primary goal being to visu-
Table 1. Survey of examined hosts and localities (see also Fig. 1).

\begin{tabular}{|c|c|c|}
\hline Hosts (examined/infected) & Localities & Coordinates \\
\hline Egretta rufescens (5/2) & $\begin{array}{l}\text { Chuburná, } \\
\text { Yucatán }\end{array}$ & $21^{\circ} 13^{\prime} 18^{\prime \prime} \mathrm{N} ; 89^{\circ} 49^{\prime} 44^{\prime \prime} \mathrm{W}$ \\
\hline Egretta rufescens (1/1) & $\begin{array}{l}\text { Punta Piedra, } \\
\text { Tamaulipas }\end{array}$ & $24^{\circ} 29^{\prime} 26^{\prime \prime} \mathrm{N} ; 97^{\circ} 45^{\prime} 01^{\prime \prime} \mathrm{W}$ \\
\hline Nycticorax nycticorax $(1 / 1)$ & $\begin{array}{l}\text { Laguna de } \\
\text { Términos, } \\
\text { Campeche }\end{array}$ & $18^{\circ} 37^{\prime} 14^{\prime \prime N} ; 91^{\circ} 34^{\prime} 43^{\prime \prime} \mathrm{W}$ \\
\hline Pelecanus occidentalis $(10 / 2)$ & $\begin{array}{l}\text { Punta Piedra, } \\
\text { Tamaulipas }\end{array}$ & $24^{\circ} 29^{\prime} 26^{\prime \prime} \mathrm{N} ; 97^{\circ} 45^{\prime} 01^{\prime \prime} \mathrm{W}$ \\
\hline
\end{tabular}

alize clustering of specimens in the morphometric space (Agustí et al. 2005). The PCA is a multivariate analysis that has been used to determine the intra- and interspecific morphological variation of helminth parasites (see Bell and Sommerville 2002, Bell et al. 2002, Agustí et al. 2005, Pinacho-Pinacho et al. 2012).

In this study two PCA analyses were performed; the first included 19 morphometric variables (see Table 2) obtained from 11 tapeworms: three from Pelecanus occidentalis Linnaeus, five from Egretta rufescens Gmelin and three from Nycticorax nycticorax Linnaeus. The second analysis included five morphometric variables of rostellar hooks obtained from eight tapeworms: one specimen from $P$. occidentalis, three of E. rufescens and three of $N$. nycticorax, including the paratype (metacestode) of G. cyprinodontis (see Table 2). Both analyses were conducted with the statistics packages PAST v. 1.60 (Hammer et al. 2001).

\section{RESULTS}

Family Gryporhynchidae Spassky et Spasskaya, 1973 Genus Glossocercus Chandler, 1935

\section{Glossocercus cyprinodontis Chandler, 1935 Figs. 2-8}

Morphological description of adults. Most of specimens studied shrunk due to fixation. Strobila large, 2.0 $6.5 \mathrm{~mm}$ (4.0 mm, $\mathrm{n}=18)$ long; maximum width 1635 . Proglottides craspedote, with convex lateral margins. Immature proglottides usually wider than long, 75-380 (225, $\mathrm{n}=85)$ long and 473-797 (571, $\mathrm{n}=85)$ wide (Fig. 2). Mature proglottides wider than long, 133-530 (310, $\mathrm{n}=65)$ long and 540-1096 (880, $\mathrm{n}=65)$ wide. Gravid proglottides wider than long, 291-550 $(410, \mathrm{n}=40)$ long and 606-1 $635(1080, \mathrm{n}=40)$ wide.

Scolex globular (Fig. 3), with maximum width at level of suckers, 302-628 (485, $\mathrm{n}=17)$ in diameter. Suckers spherical, with weakly to moderately developed musculature, 98-177 $(140, \mathrm{n}=68)$ in diameter. Rostellum retractable, protrusible, with thick longitudinal muscular fibres, subglobular pad bearing hooks and short stem; anterior surface of pad slightly concave (forming small anterior depression), entire length of fully extended rostellum 690 $(\mathrm{n}=1)$, maximum width at anterior pad $250(\mathrm{n}=1)$; most of rostella folded within rostellar pouch; in few cases, rostella contracted, with stem slightly wider than apical muscular pad; diameter of pad 127-301 (203, n=17). Rostellar pouch as long as wide, $153-278(200, \mathrm{n}=18)$ long and $120-272(199, \mathrm{n}=18)$ wide; thick-walled, oval to pyriform, reaching to level of suckers. Rostellar pouch with 

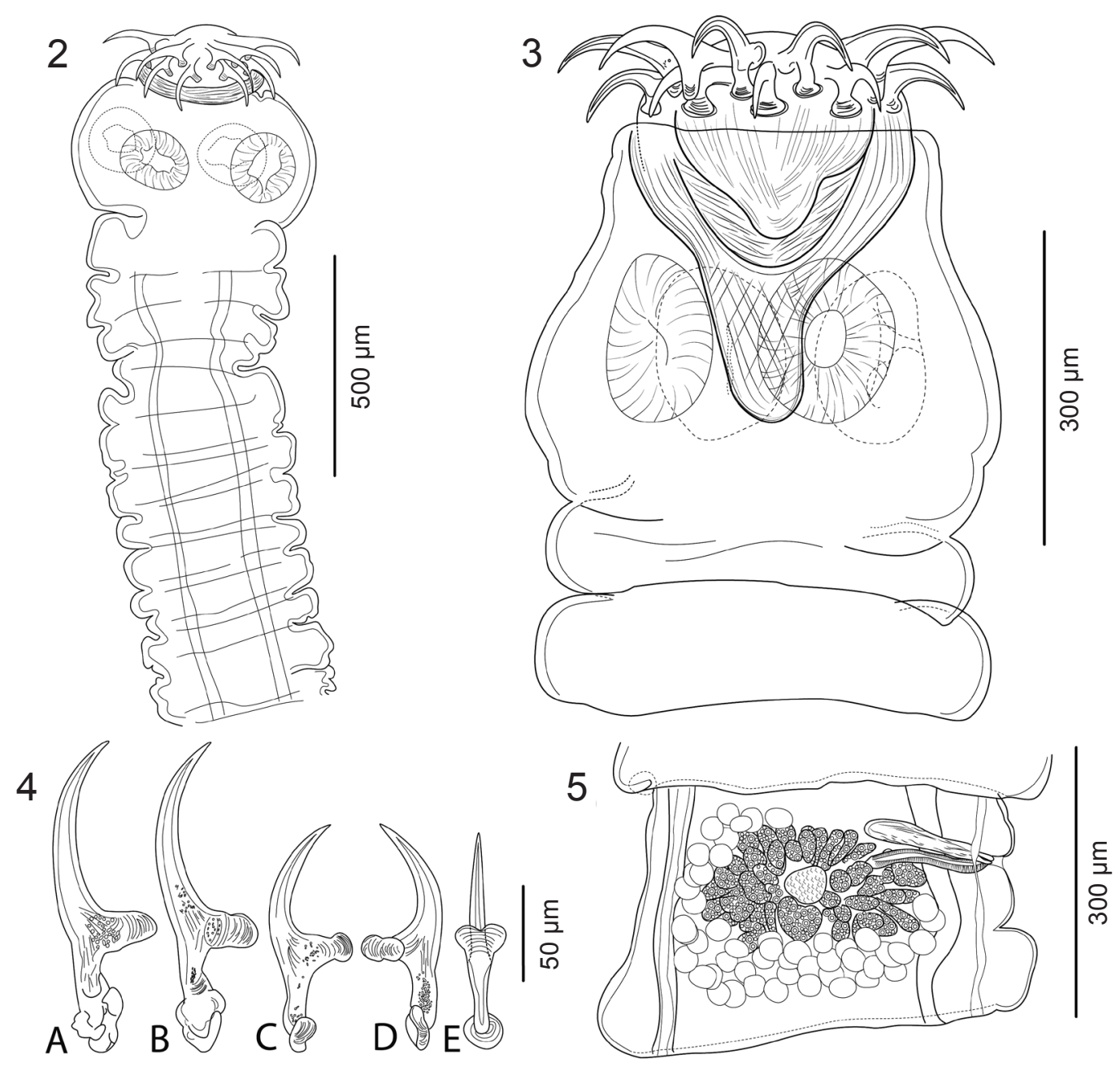

Figs. 2-5. Glossocercus cyprinodontis. Fig. 2. Anterior view of G. cyprinodontis from Nycticorax nycticorax from Laguna de Términos, Campeche. Fig. 3. Scolex of G. cyprinodontis from Pelecanus occidentalis from Punta Piedra, Tamaulipas. Fig. 4. Rostellar hooks of $G$. cyprinodontis from $N$. nycticorax from Laguna de Términos, Campeche. A, B - distal hooks, $\mathbf{C}-\mathbf{E}-$ proximal hooks. Fig. 5. Mature proglottis of G. cyprinodontis from P. occidentalis from Punta Piedra, Tamaulipas.

radially arranged longitudinal fibres. Rostellar hooks 20 $(\mathrm{n}=16)$ in number, arranged in two regular rows; anterior and posterior hooks with different shape. Distal hooks 163-198 (179, $\mathrm{n}=21)$ long; with robust guard directing forward, merging with the handle; blade longer than handle; blade $80-163(109, \mathrm{n}=57)$ long; handle $63-88$ $(80, \mathrm{n}=21)$ long, tapered to its end of distal hooks; blade/ handle ratio $1.05-1.84(1.40, \mathrm{n}=21)$ (Fig. 4). Proximal hooks $105-155(135, \mathrm{n}=34)$ long, with blade longer than handle; guard forming angle almost $90^{\circ}$ to axis of handle; blade and handle of almost equal in length, blade 58-93 $(72, \mathrm{n}=61)$ long; handle 48-80 $(65, \mathrm{n}=35)$ long, tapered to its end of proximal hooks; blade/handle ratio 0.86-1.54 (1.15, n=34) (Fig. 4).

Strobila protandrous. Genital pores irregularly alternating, situated far anterior. Genital atrium thick-walled, base slightly expanded. Genital ducts between osmoregulatory canals. Ventral osmoregulatory canals 20-78 (34, $\mathrm{n}=140$ ) wide, with transverse anastomosis along pos- terior margin of each proglottis. Dorsal osmoregulatory canals $5-14(9, \mathrm{n}=90)$ wide.

Testes spherical, 20-39 $(30, \mathrm{n}=75)$ in number, surround ovary completely (Fig. 5), 37-50 in diameter (43, $\mathrm{n}=80$ ). External vas deferens strongly coiled, divided into prostate and aprostate parts; prostate part covered by intensely stained cells forming compact body, usually overlapping cirrus-sac near anterior proglottis margin; aprostate part forming numerous coils antiporally and posteriorly to cirrus-sac and prostate part of vas deferens, often reaching posteriorly to level of seminal receptacle and ovary (Fig. 6). Cirrus-sac (Fig. 6) elongate, thickwalled, between osmoregulatory canals, 185-282 (245, $\mathrm{n}=80)$ long and 35-87 $(42, \mathrm{n}=80)$ wide. Evaginated cirrus cylindrical, 16-20 $(16, \mathrm{n}=24)$ long, armed with small and delicate spinitriches shorter than $1 \mu \mathrm{m}$; apical tuft with slender spinitriches about 25 long (Fig. 7).

Vitelline follicles situated in middle of proglottis. Ovary transversely elongate with fan-shaped lobes (Fig. 5); 


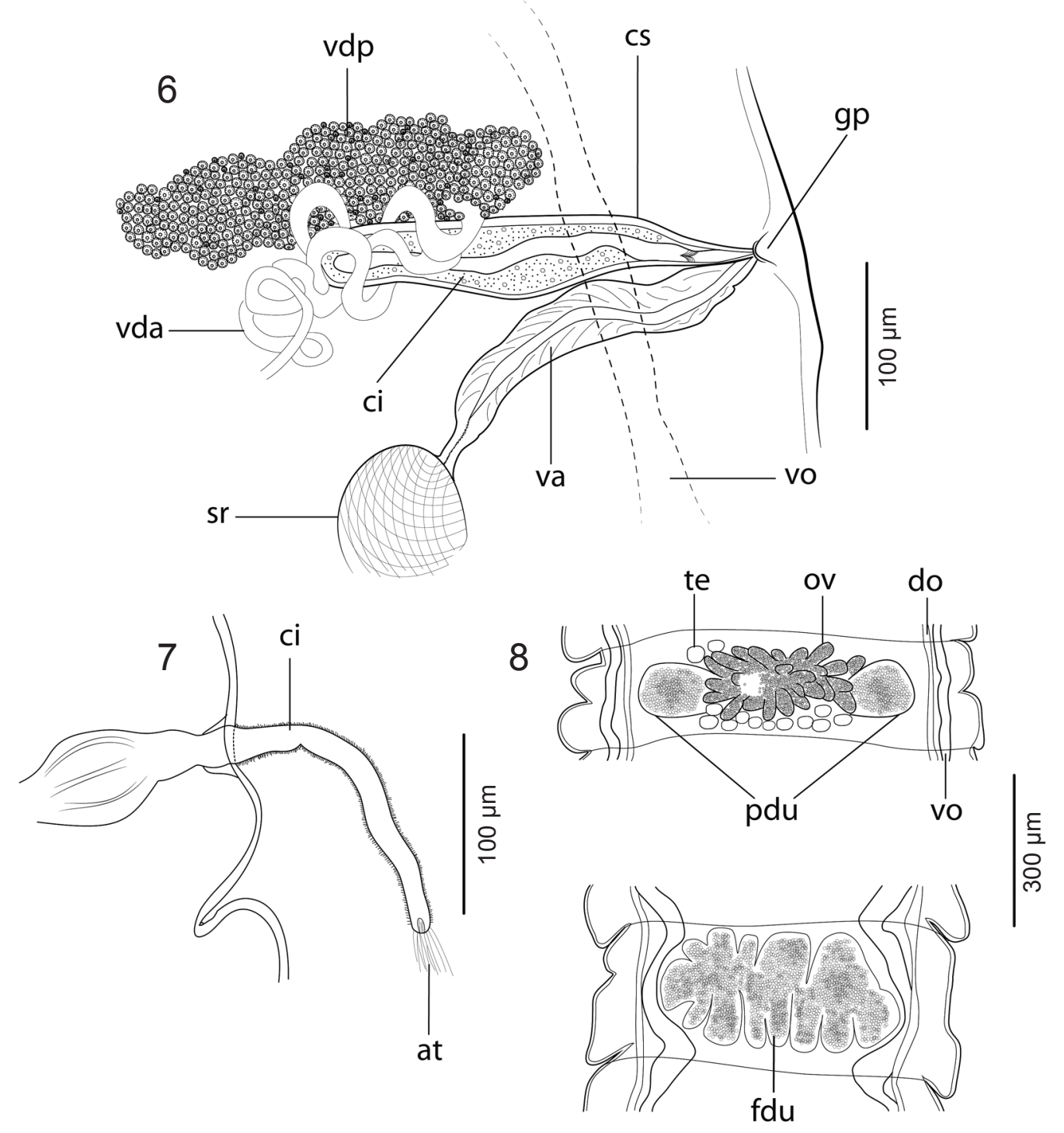

Figs. 6-8. Glossocercus cyprinodontis from Pelecanus occidentalis from Punta Piedra, Tamaulipas. Fig. 6. Genital ducts. Fig. 7. Cirrus. Fig. 8. Uterus. Abbreviations: at - apical tuft; ci - cirrus; cs - cirrus-sac; do - dorsal osmoregulatory canal; fdu - fully developed uterus; gp - genital pore; ov - ovary; pdu- partially developed uterus; sr - seminal receptacle; te - testes; va - vagina; vda - external vas deferens aprostate; vdp - external vas deferent prostate; vo - ventral osmoregulatory canal.

lobules large, thick, most prominent anteriorly when ripe; lobes contiguous by a single mass. Mehlis' gland not observed. Seminal receptacle oval, 52-122 $(80, \mathrm{n}=56)$ long and $42-175(76, \mathrm{n}=56)$ wide, situated in middle of proglottis, surrounded by ovary. Vagina transverse, straight, surrounded by epithelial cells, internally lined with hyaline layer visible up to thin proximal extremity indicating end of vagina and beginning of seminal receptacle; vaginal canal ventral, of equal length as cirrus-sac; vagina $18-35(25, \mathrm{n}=30)$ wide; lumen of vaginal canal $7-28(22, n=25)$ wide (Fig. 5). Uterine primordium barshaped, posterior to ovary in mature proglottides. Fully developed uterus occupies entire space of proglottides between osmoregulatory ducts, with diverticula filled with eggs (Fig. 8). Mature eggs not seen, apparently due to apolytic nature of proglottides.
Ty pe host: Cyprinodon variegatus Lacépède (Cyprinodontiformes: Cyprinodontidae) (metacestodes).

Type locality: Galveston Bay, Texas.

Site of infection: Mesentery.

Definitive hosts: Egretta rufescens, Nycticorax nycticorax (Pelecaniformes: Ardeidae), Pelecanus occidentalis (Pelecaniformes: Pelecanidae).

Other localities (adult specimens): Campeche: Laguna de Términos, Tamaulipas: Punta Piedra, Yucatan: Chuburná.

Site of infection: Intestine.

Specimens deposited: CNHE 8264-8267; USNPC 105875-105877.

Remarks. The adults of G. cyprinodontis, G. caribaensis, and G. auritus have been recorded in North America including Mexico, Brazil, Nicaragua, and the Caribbean 
(Bona 1994, Ortega-Olivares et al. 2008). Glossocercus cyprinodontis differs from two other congeneric species, i.e. G. caribaensis and G. auritus, in the size and shape of the rostellar hooks, which are smaller in the former species (see Table 3 and Fig. 9). The guard of G. cyprinodontis is directed forward and merges with the handle in the distal hooks, whereas that of G. caribaensis is inclined posteriorly and separated by two discontinuous lines, and that of G. auritus is directed forward, being separated by one sclerified line (Fig. 9).

Glossocercus cyprinodontis was described from metacestodes based on the morphology of the rostellar hooks. Bona (1994) provided a generic diagnosis of Glossocercus based on the metacestodes of the type species (morphology of rostellar hooks) and other congeneric species (hook morphology and strobilar characteristics). However, the generic diagnosis was incomplete because the morphological features of the adult of the type species were unknown. In the present study adult specimens identified as $G$. cyprinodontis were collected from their definitive hosts, which made it possible to provide the correct generic diagnosis of Glossocercus.

\section{Generic diagnosis}

Cyclophyllidea: Gryporhynchidae. Strobila large. Proglottides craspedote with convex lateral margins and wider than long. Scolex large and globular. Rostellum retractable. Rostellar pouch as long as wide. Rostellar hooks arranged in two regular rows with ten hooks in each; anterior and posterior hooks of different shape and length. Strobila protandrous. Genital pores irregularly alternating, situated far anterior. Genital ducts between osmoregulatory canals. Testes spherical, surround ovary completely. Cirrus-sac elongate, wall thick, between osmoregulatory canals. Cirrus armed with spinitriches and
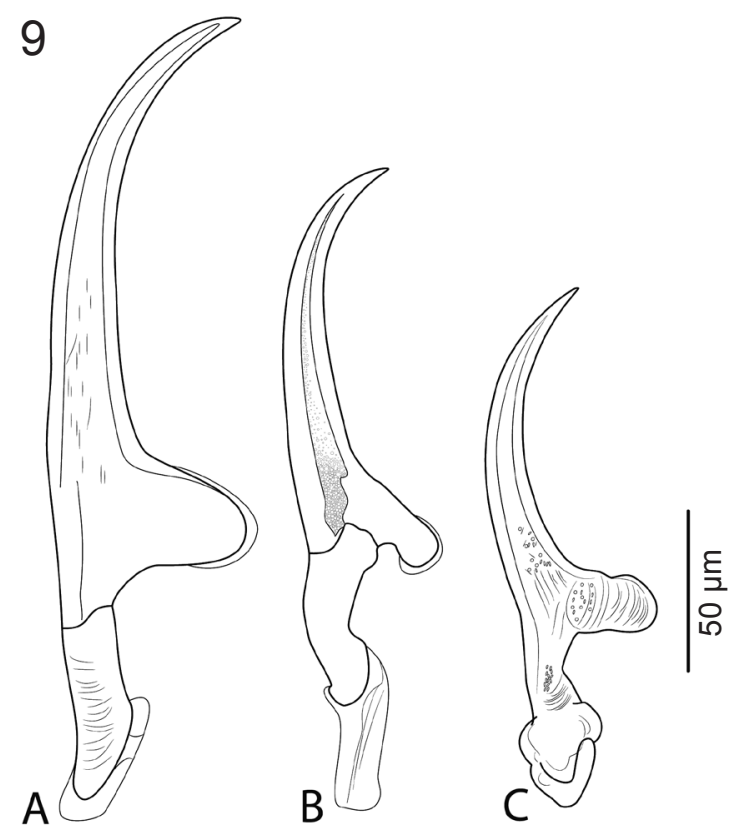

Fig. 9. Rostellar hooks of the species of Glossocercus in America. A - Glossocercus auritus from Egretta caerulea (modified from Ortega-Olivares et al. 2008); B - Glossocercus caribaensis from Egretta rufescens; C - Glossocercus cyprinodontis from Nycticorax nycticorax.

apical tuft of slender spinitriches. Vitelline follicles in the middle of proglottis. Ovary lobed, slightly transversely elongate, in middle of proglottis; lobes contiguous and by a single mass. Seminal receptacle oval, situated in middle of proglottis. Vagina transverse, straight, surrounded by epithelial cells, ventral to cirrus-sac and of equal length. Uterus bar-shaped, posterior to ovary in mature proglottides. Fully developed uterus occupies all space between osmoregulatory ducts, with diverticula filled with eggs.
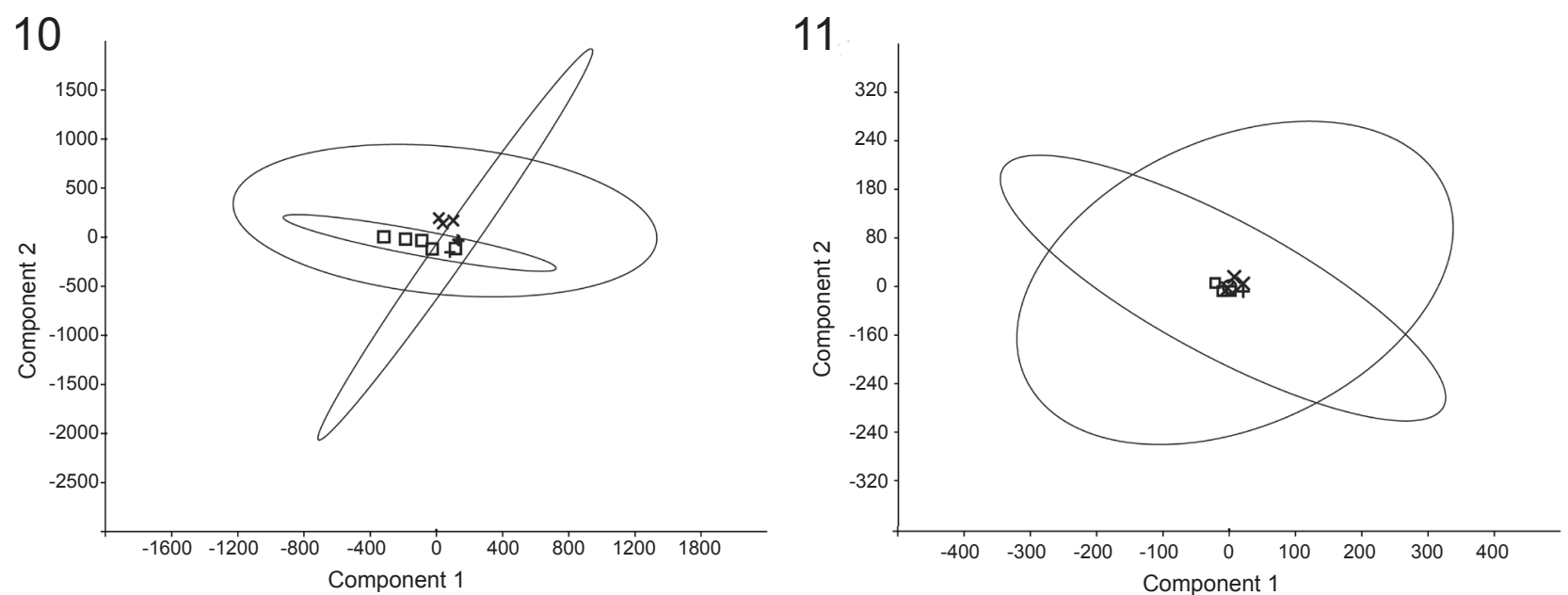

Figs. 10, 11. Principal component analyses. Fig. 10. PCA conducted with 19 morphometrical variables of the adults of Glossocercus cyprinodontis from three definitive host species. Fig. 11. PCA conducted with five morphometrical variables of the rostellar hooks of the adults from three definitive host species and one paratype of G. cyprinodontis. Specimens of G. cyprinodontis from Egretta rufescens are represented by $\square$, Nycticorax nycticorax by $\times$, Pelecanus occidentalis by + , and Cyprinodon variegatus (paratype) by $\gamma$. 
Table 2. Comparative measurements Glossocercus cyprinodontis using for the PCA analyses.

\begin{tabular}{llllc}
\hline Characters & $\begin{array}{l}\text { G.cyprinodontis } \\
\text { Pelecanus occidentalis }\end{array}$ & $\begin{array}{l}\text { G. cyprinodontis } \\
\text { Egretta rufescens }\end{array}$ & $\begin{array}{l}\text { G.cyprinodontis } \\
\text { Nycticorax nycticorax }\end{array}$ & $\begin{array}{l}\text { G. cyprinodontis } \\
\text { Cyprinodon variegatus }\end{array}$ \\
\hline Stage & Adult & Adult & Adult & Metacestode \\
Total length body (mm) & $3.6-6.1(4.1)$ & $2.7-6.2(4.5)$ & $2.0-4.6(3.3)$ & - \\
Scolex length & $329-406(374)$ & $312-388(350)$ & $454-594(541)$ & - \\
Scolex width & $414-566(486)$ & $357-508(447)$ & $517-549(536)$ & - \\
Pad width & $157-210(189)$ & $127-175(151)$ & $256-301(253)$ & - \\
Rostellum sac length & $157-192(178)$ & $153-218(191)$ & $176-229(203)$ & - \\
Rostellum sac width & $165-272(229)$ & $120-219(179)$ & $143-251(209)$ & - \\
Sucker diameter & $211-261(242)$ & $197-236(218)$ & $292-314(302)$ & - \\
Immature proglottides length & $252-350(297)$ & $191-244(227)$ & $164-254(219)$ & - \\
Immature proglottides width & $540-576(560)$ & $510-784(598)$ & $490-585(531)$ & - \\
Mature proglottides length & $304-502(378)$ & $274-337(321)$ & $252-333(296)$ & - \\
Mature proglottides width & $924-1000(967)$ & $568-1003(777)$ & $788-888(841)$ & - \\
Testes number & $34-36(35)$ & $21-35(29)$ & $20-31(26)$ & - \\
Diameter testes & $41-46(43)$ & $42-46(44)$ & $40-44(43)$ & - \\
Cirrus length & $271-315(293)$ & $290-324(314)$ & $297-339(318)$ & - \\
Cirrus width & $49-55(51)$ & $48-57(53)$ & $50-52(51)$ & - \\
Ventral osmoregulatory width & $8.2-10.1(9.0)$ & $6.7-11.5(9.4)$ & $7.8-8.3(8.1)$ & - \\
Dorsal osmoregulatory width & $189-224(209)$ & $185-203(196)$ & $243-251(246)$ & - \\
Seminal receptacle length & $65-99(85)$ & $61-92(81)$ & $66-82(75)$ & 170 \\
Seminal receptacle width & $78-164(127)$ & $47-61(54)$ & $50-67(56)$ & 88 \\
Distal hooks & & & & \\
Length & 198 & $163-180(172)$ & $175-191(181)$ & 1.2 \\
Blade & 109 & $96-105(101)$ & $106-122(115)$ & 74 \\
Handle & 88 & $63-83(74)$ & $74-86(80)$ & \\
Ratio B/H & 1.2 & $1.2-1.6(1.4)$ & $1.2-1.6(1.4)$ & \\
Proximal hooks & & $63-71(66)$ & $67-85(75)$ & \\
Blade & 73 & & \\
\hline
\end{tabular}

Table 3. Measures and morphological characters of the rostellar hooks of three species of Glossocercus in America.

\begin{tabular}{|c|c|c|c|}
\hline Characters & G. cyprinodontis ${ }^{1,2,3,7}$ & G. auritus ${ }^{2,3,5,6}$ & G. caribaensis $^{2,3,4,6}$ \\
\hline \multicolumn{4}{|l|}{ Distal hooks } \\
\hline Length & $175-203$ & $220-285$ & $189-211$ \\
\hline Blade & $100-128$ & $140-195$ & $101-132$ \\
\hline Handle & $71-96$ & $82-160$ & $72-97$ \\
\hline \multicolumn{4}{|l|}{ Proximal hooks } \\
\hline Length & $128-150$ & $160-224$ & $120-151$ \\
\hline Blade & $71-86$ & $93-138$ & $52-83$ \\
\hline Handle & $60-86$ & $83-120$ & $56-78$ \\
\hline Position of the guard & directed forward & directed forward & posteriorly inclined \\
\hline Guard & $\begin{array}{l}\text { merges with handle; } \\
\text { strongly sclerified }\end{array}$ & $\begin{array}{l}\text { separated from handle } \\
\text { by one line sinuous; smooth }\end{array}$ & $\begin{array}{l}\text { separated from handle } \\
\text { by two discontinuous lines; smooth }\end{array}$ \\
\hline Handle & strongly sclerified & sclerified & smooth \\
\hline
\end{tabular}

References: 1. Chandler 1935; 2. Scholz et al. 2004; 3. Ortega-Olivares et al. 2008; 4. Schmidt and Courtney 1973; 5. Scholz et al. 2002; 6. Rysavy and Macko 1973; 7. Current study.

\section{Principal component analysis}

The first analysis includes 19 morphological characters of the adult: total length of body, immature proglottides length, immature proglottides width, mature proglottides length, mature proglottides width, scolex length, scolex width, pad width, rostellar pouch length, rostellar pouch width, sucker diameter, number of testes, testes diameter, cirrus length, cirrus width, seminal receptacle length, seminal receptacle width, ventral osmoregulatory canals width, and dorsal osmoregulatory canals width. The first component explains $39 \%$ of the variance and the second component explains 26\% of variance (Fig. 10). The second analysis included data on five morphological traits related to rostellar hooks of the adults and the metacestode (paratype): total length, length of blade (B), length of handle $(\mathrm{H})$, the ratio $\mathrm{B} / \mathrm{H}$ of distal hooks, and the length of blade of proximal hooks. The first component explains $64 \%$ of variance and the second component explains $22 \%$ of variance (Fig. 11). The first analysis shows that morphological characters of adults from different definitive hosts do not differ significantly, which indicates that the specimens belong to the same taxon. The second analysis also 
shows that rostellar hooks of adults and the metacestode (paratype) do not differ significantly from each other and seem to belong to the same species (Figs. 10, 11).

\section{DISCUSSION}

Gryporhynchidae is a family of tapeworms classified into 14 genera parasitizing fish-eating birds throughout the world (Bona 1994, Pichelin et al. 1998, Scholz and Salgado-Maldonado 2001, Scholz et al. 2002, 2004, 2008, Ortega-Olivares et al. 2008, Presswell et al. 2012). In Mexico eight genera have been previously recorded, namely Cyclustera Fuhrmann, 1901; Dendrouterina Fuhrmann, 1912; Glossocercus Chandler, 1935; Neogryporhynchus Baer et Bona, 1975; Neovalipora Baer, 1962; Paradilepis Hsu, 1935; Parvitaenia Burt, 1940; and Valipora Linton, 1927 (Vidal-Martínez et al. 2001, Ortega-Olivares et al. 2008, 2011, Pérez-Ponce de León et al. 2010).

Currently, Glossocercus comprises nine species that are characterized morphologically by having a 'glossocercoid' rostellar hook pattern. Chandler (1935) described G. cyprinodontis as type species from metacestodes. However, the diagnosis was based on the morphology of the rostellar hooks. Bona (1994) provided a generic diagnosis of Glossocercus, which could not be based on strobilar morphology of the type species known only as larvae (metacestodes) from fish and never found since the original description by Chandler (1935).

In the present study, strobilar morphology of G. cyprinodontis is described for the first time, based on specimens from three different definitive hosts (herons). Statistical comparison of measurements of tapeworms from these hosts has shown that they are conspecific and thus the morphological description of adults is based on pooled from three bird species.

To test the phenotypic variation of the adults of G. cyprinodontis, 11 specimens from three definitive hosts were analyzed using 19 morphological characters. The PCA strongly supported that the specimens belong to the same species because values for specimens from individual hosts overlapped and were not separated to distinct clusters. The same pattern was found using the morphological character diagnostic (rostellar hooks), including the paratype (metacestode) and adults. This PCA showed that all the specimens analyzed in this study represents single species (Figs. 10, 11). These analyses indicate that the specimens collected from fish-eating birds are conspecific with the metacestode of G. cyprinodontis. To confirm conspecifity of adults from different hosts, sequences of the small subunit of rDNA were obtained from six adults. All these specimens formed a single clade with low nucleotide differences (ranging from 0 to $0.02 \%$ ) which indicates conspecificity of specimens from different definitive hosts (unpublished data).

Acknowledgments. We thank David Hernández Mena and Carlos Daniel Pinacho Pinacho from IBUNAM, and Armando Cardoso and Narciso Salinas from the Universidad de Nuevo León, Monterrey for invaluable help in the field. Manuel Rosado Luna helped with the drawings. This research was supported by Consejo Nacional de Ciencia y Tecnología (CONACyT No. 179048) and Programa de Apoyo a Proyectos de Investigación e Inovación Tecnológica (PAPIIT No. 215709). MPOO appreciates support of the Programa de Posgrado en Ciencias Biológicas, UNAM and is obliged to CONACyT for the scholarship No.164765. This paper forms part of $\mathrm{PhD}$ thesis of the senior author.

\section{REFERENCES}

Agustí C., Aznar F.J., Raga J.A. 2005: Tetraphyllidean plerocercoids from western Mediterranean cetaceans and other marine mammals around the world: a comprehensive morphological analysis. J. Parasitol. 91: 83-92.

Bell A.S., Sommerville C. 2002: Molecular evidence for the synonymy of two species of Apatemon Szidat, 1928, A. gracilis (Rudolphi, 1819) and A. annuligerum (von Nordmann, 1832) (Digenea: Strigeidae) parasitic as metacercariae in British fishes. J. Helminthol. 76: 193-198.

Bell A.S., Sommerville C., Gibson D.I. 2002: Multivariate analyses of morphometrical features from Apatemon gracilis (Rudolphi, 1819) Szidat, 1928 and A. annuligerum (v. Nordmann, 1832) (Digenea: Strigeidae) metacercriae. Syst. Parasitol. 51: 121-133.

Bona F.V. 1994: Family Dilepididae Railliet \& Henry, 1909. In: L.F. Khalil, A. Jones and R.A. Bray (Eds.), Keys to the Cestode Parasites of Vertebrates. CABI, Wallingford, pp. 443-554.

Chandler A.C. 1935: Parasites of fishes in Galveston Bay. Proc. U. S. Nat. Mus. 83: 123-157+ 7 plates.

Hammer Ø., Harper D.A, Ryan P.D. 2001: PAST: Paleontological Statistics Software Package for education and data analysis. Palaeontol. Electron. 4: 9.
Ortega-Olivares M.P., Barrera-Guzmán A.O., Haasová I., Salgado-Maldonado G., Guillén-Hernández S., Scholz T. 2008: Tapeworms (Cestoda: Gryporhynchidae) of fisheating birds (Ciconiiformes) from Mexico: new host and geographical recods. Comp. Parasitol. 75: 182-195.

Ortega-Olivares M.P., Hernández-Mena D.I., Pérez-Ponce de León G., García-Varela M. 2011: Helminths of the white ibis, Eudocimus albus (Aves: Threskiornithidae) in Mexico. Zootaxa 3088: 15-26.

Pérez-Ponce de León G., Rosas-Valdez R., Aguilar-Aguilar R., Mendoza-Garfias B., Mendoza-Palmero C., GarcíaPrieto L., Rojas-Sanchéz A., Brioso-Aguilar R., PérezRodríguez R., Domínguez-Domínguez O. 2010: Helminth parasites of freshwater fishes, Nazas River basin, northern Mexico. Checklist 6: 26-35.

Pichelin S., CribB T.H., Bona F.V. 1998: Glossocercus chelodinae (MacCallum, 1921) n. comb. (Cestoda: Dilepididae) from freshwater turtles in Australia and a redefinition of the genus Bancroftiella Johnston, 1911. Syst. Parasitol. 39: 165-181.

Pinacho-Pinacho C.D., Pérez-Ponce de León G., GarcíaVArela M. 2012: Description of a new species of Neoechinorhynchus (Acanthocephala: Neoechinorhynchidae) a parasite of Dormitator latifrons from southwestern Mexico based on 
morphological and molecular characters. Parasitol. Int. 61: 634-644.

Presswell B., Poulin R., Randhawa H.S. 2012: First report of a gryporhynchid tapeworm (Cestoda: Cyclophyllidea) from New Zealand and from an eleotrid fish, described from metacestodes and in vitro-grown worms. J. Helminthol. 86: 453464.

Rysavy B., Macko J.K. 1973: Bird cestodes of Cuba I. Cestodes of birds of the orders Podicipediformes, Pelecaniformes and Ciconiiformes. An. Inst. Biol. UNAM, Serie Zool. 1: 1-28.

Schmidt G.D., Courtney C.H. 1973: Parvitaenia heardi sp. n. (Cestoidea: Dilepididae) from the great blue heron, Ardea herodias, in South Carolina. J. Parasitol. 59: 821-823.

Scholz T., Boane C., Saraiva A. 2008: New metacestode of gryporhynchid tapeworms (Cestoda: Cyclophyllidea) from carp (Cyprinus carpio Linnaeus, 1758) from Mozambique, Africa. Comp. Parasitol. 75: 315-320.

Scholz T., Bray R.A., Kuchta R., Řepová R. 2004: Larvae of gryporhynchid cestodes (Cyclophyllidea) from fish: a review. Folia Parasitol. 51: 131-152.

Scholz T., Kuchta R., Salgado-Maldonado G. 2002: Cestodes of the family Dilepididae (Cestoda: Cyclophyllidea) from fisheating birds in Mexico: a survey of species. Syst. Parasitol. 52: 171-182.

Scholz T., Salgado-Maldonado G. 2001: Metacestodes of the family Dilepididae (Cestoda: Cyclophyllidea) parasitizing fishes in Mexico. Syst. Parasitol. 49: 23-40.

Vidal-Martínez V.M., Aguirre-Macedo L., Scholz T., GonzÁlez-Solís D. 2001: Atlas of the Helminth Parasites of Cichlid Fish of Mexico. Academia, Prague, 166 pp. 